\title{
Monitoring of Antimicrobial Activity of Essential Oils Using Molecular Markers
}

\author{
Hend A. Hamedo* \\ El Arish, Faculty of Education, Suez Canal University, Egypt
}

\begin{abstract}
Technological application of essential oils, as natural antimicrobial agents, to reduce the effect of pathogenic microorganisms, requires new methods of detection. The present work evaluated the parameters of antimicrobial activity of the essential oils of rosemary (Rosmarinus officinalis) on two pathogenic strains Escherichia coli and Staphylococcus aureus. The MBC and MIC values were of 2.5, $25 \mu \mathrm{ml}^{-1}$, and values of 1.25 and $5 \mu 1 \mathrm{ml}$ for the two strains respectively. In this study, an attempt has been made to evaluate randomly amplified polymorphic DNA (RAPD) analysis for its potential to establish antimicrobial effect of rosemary essential oil. For the preliminary assessment, this study compared the effects occurring at molecular levels in E. coli and Staph. aureus exposed to rosemary essential oil at the MIC concentrations for the two organisms. The qualitative modifications arising in random amplified polymorphic DNA (RAPD) profiles as a measure of DNA effects were compared with control which showed many differences. In conclusion, the measurement of parameters at molecular levels is valuable for investigating the specific effects of agents interacting with DNA.
\end{abstract}

Keywords: RAPD-PCR, Rosemary essential oil, Escherichia coli, Staphylococcus aureus.

\section{INTRODUCTION}

In recent years there has been an increasing interest in the use of natural substances, and some questions concerning the safety of synthetic compounds have encouraged more detailed studies of plant resources. Essential oils are concentrated, hydrophobic liquid containing volatile aromatic compounds from plant. They posses a wide spectrum of pharmacological activities. The antimicrobial effects of essential oils have been documented and used in herbal medicine in many countries [1-3]. The main advantage of natural agents is that they do not enhance the "antibiotic resistance", a phenomenon commonly encountered with the long-term use of synthetic antibiotics.

Antibacterial effects of hydrous, methanolic and ethanolic extracts of clove, cinnamon, sage, thyme and rosmarinus on Gram- positive and Gram- negative bacteria had previously been investigated. The results showed that all of these plants had antibacterial action on methicillin-resistant Staphylococcus aureus (MRSA) and Bacillus subtilis [4], but they were weakly active against Gram-negative bacteria such as Pseudomonas aeruginosa and enteropathogenic Escherichia coli [5]. Gram-negative bacteria are more resistant to antibiotics than the Gram-positive bacteria due to the permeability barrier provided by the cell wall or to the membrane accumulation mechanism [6].

To reduce health hazards and economic losses due to foodborne microorganisms, the use of natural products as antibacterial compounds seem to be an interesting way to control the presence of pathogenic bacteria and to extend the shelf life of processed food [7,8]. These compounds could be added during the food process. Among these products,

*Address correspondence to this author at the El Arish, Faculty of Education, Suez Canal University, Egypt; E-mail: hend_hamedo@hotmail.com essential oils from spices, medicinal plants and herbs have been shown to possess antimicrobial activities and could serve as a source of antimicrobial agents against food pathogens $[9,10]$. Several references on the antimicrobial and antifungal efficiency of essential oils are available in the literature $[11,12]$.

Rosemary essential oil was used as antibacterial, antifungal, antiseptic agents. It is largely used in traditional medicine, in perfumery, phytocosmetic and in liquors manufacturing $[13,14]$. They have been the subject of considerable studies $[15,16]$. Their antimicrobial activity is summarized by Burt [17]. The qualitative composition of rosemary EOs is well defined and fixed. Also it used as general stimulant, improves circulation, treats rheumatic pains, and useful for skin care.

Nucleic acid amplification technology has opened new avenues of microbial detection and characterization $[18,19]$, such that growth is no longer required for microbial identification [20-22]. In this respect, molecular methods have surpassed traditional methods of detection for many fastidious organisms. The polymerase chain reaction (PCR) and other recently developed amplification techniques have simplified and accelerated the in vitro process of nucleic acid amplification. The amplified products, known as amplicons, may be characterized by various methods. Rapid techniques of nucleic acid amplification and characterization have significantly broadened the microbiologists' diagnostic arsenal.

Randomly amplified polymorphic DNA (RAPD), a technique based on the PCR using primers of arbitrary sequence, has been used increasingly for taxonomic, identification and isolate differentiation in a variety of organisms [23-25]. It has also been introduced for genetic characterization of many organisms such as Escherchia coli and Staphylococcus aureus $[26,27]$. 
The detection of DNA damage has been widely studied using a number of laboratory methods, to investigate the effect of mutagens on different organisms. However, molecular markers allow a direct comparison of the effects of genotypes at the DNA level. The explorations of random amplified polymorphic DNA (RAPD) as genetic markers have improved the detection of DNA alterations after the influence of many agents [28]. The different types of DNA damages must be detected by changes in RAPD profiles.

In the context of the information provided above, the objectives of this study have been, to investigate the possibility of mutation changes in two kinds of Gram -ve and Gram +ve bacteria (Escherchia coli and Staphylococcus aureus) after the influence of rosemary essential oil using RAPD method, to determine whether the RAPD assay could detect changes in bacterial DNA, and to assess how these endpoints (i.e. changes in RAPD profile) compare in terms of detection of antimicrobial activity. The main purpose of this study is to evaluate the potential antimicrobial activity of rosemary essential oil, via the RAPD assay. Thus a preliminary investigation was undertaken to study the capability of this technique to show mutagenic effects induced by essential oils.

\section{MATERIALS AND METHODS}

\section{Preparation of Essential Oils}

The volatile oil of rosemary (Rosmarinus officinalis) was extracted from the above ground air dried parts (Shoot system) using steam-distillation apparatus for 3 hours. The oils obtained were separately dried over anhydrous sodium sulphate [29].

\section{Microbial Strains and Culture Conditions}

The essential oils were individually tested against the two microorganisms, Escherichia coli and Staphylococcus aureus. These strains were obtained from Department of Botany, Faculty of Science, Mansoura University. The Bacteriological agar and nutrient broth were provided from Difco.

\section{MIC and MBC Determinations}

The minimum inhibitory concentration (MIC) was defined as the lowest concentration that prevent visible growth of the bacteria $[11,30]$. The minimum bactericidal concentration (MBC) was determined as a concentration where $99.9 \%$ or more the initial inoculum is killed $[30,31]$. The rosemary essential oils was dissolved in Tween-80 (0.05\%). The MIC and MBC concentrations were determined by serial dilution with nutrient broth. The bacterial cell number was adjusted at $10^{6}$ bacterial cells $/ \mathrm{ml}(0.1 \mathrm{ml}$ inoculum / tube $)$ for the two strains tested. All samples were incubated at $37^{\circ} \mathrm{C}$ during 18-24 h. To confirm results of $\mathrm{MBC}$, the experimental suspensions were sub-cultured in nutrient agar plates according to the method described by Ronda [32] and were incubated at $37^{\circ} \mathrm{C}$ during $18-24 \mathrm{~h}$. We have used this method because it is more sensitive than the agar dilution.

\section{DNA Isolation}

The isolation of genomic DNA from the two tested organisms (E. coli and Staph. aureus) was performed using the Cetyl Trimethyl Ammonium Bromide (CTAB) method [33].
$0.5 \mathrm{gm}$ of fresh samples (organism exposed to oil and control for every organism) was ground to powder in liquid nitrogen with a prechilled pestle and mortar, suspended in $5 \mathrm{ml}$ preheated CTAB buffer, and incubated at $65^{\circ} \mathrm{C}$ for 1 hour with occasional shaking. The suspension was then mixed with $1 / 3$ volume of chloroform, mixed gently, centrifuged and the upper phase was transferred to a new sterilized tube. Extraction was repeated with an equal volume of chloroform. The aqueous layer was transferred to a new tube, $2 / 3$ volume of isopropanol was added and nucleic acids were either spooled using a Pasteur pipette or sedimentated by centrifugation. The pellet was washed carefully twice with $70 \%$ ethanol, dried at room temperature and resuspended in $0.5 \mathrm{ml} \mathrm{TE}$ buffer. The enzyme, RNAse A $(20 \mu \mathrm{g})$ was added to the resuspended mixture to digest any contaminating RNA and the tube was incubated at $37{ }^{\circ} \mathrm{C}$ for $30 \mathrm{~min}$. To remove the enzyme and other contaminating protein, phenol/chloroform extraction was performed.

\section{Random Amplified Polymorphic DNA (RAPD) Analy- sis}

The polymerase chain reaction (PCR) mixture was prepared as following in 25 ul PCR tubes: genomic DNA 50 $\mathrm{ng} / \mathrm{ml}, 25 \mathrm{pmol}$ dNTPs, and $25 \mathrm{pmol}$ of random primer $(\mathrm{Op}-$ eron Technologies Inc.,) consisted of 0.8 units of Taq DNA polymerase. The reaction mixture was placed on a DNA thermal cycler. The PCR programme included an initial denaturation step at $94^{\circ} \mathrm{C}$ for 2 mins followed by 45 cycles with $94^{\circ} \mathrm{C}$ for $1 \mathrm{~min}$ for DNA denaturation, annealing as mentioned with each primer, extension at $72^{\circ} \mathrm{C}$ for $30 \mathrm{sec}$ onds and final extension at $72{ }^{\circ} \mathrm{C}$ for 10 minutes were carried out. A set of five 10-mer primers (Operon technologies Inc., Alameda, California) randomly selected were used in RAPD analysis (Table 1).

Table 1. List of Random Primers Used for RAPD Analysis

\begin{tabular}{|c|c|c|}
\hline Primer & Sequence 5'-3' & Annealing Temp ${ }^{\circ} \mathbf{C} / \mathbf{S e c}$ \\
\hline \hline A1 & TGGCGACCTG & \multirow{2}{*}{$36^{\circ} \mathrm{C}$} \\
\hline A2 & GAGGCGTCGC & \\
\hline B1 & CCCTACCGAC & \\
\hline B2 & TCGTTCCGC & \\
\hline B3 & CACCTTTCCC & \\
\hline
\end{tabular}

\section{Gel Electrophoresis}

The amplification products were analyzed by electrophoresis [34]. Along with the PCR amplified products, $100 \mathrm{bp}$ DNA ladders (Promega) as standard marker were subjected to electrophoresis in $2 \%$ agarose gel in TAE buffer (for each litre of 50X TAE Stock solution: $242 \mathrm{~g}$ Tris Base, $57.1 \mathrm{~mL}$ Glacial Acetic Acid and $100 \mathrm{~mL} \mathrm{0.5} \mathrm{M} \mathrm{EDTA} \mathrm{),} \mathrm{and} \mathrm{stained}$ with ethidium bromide. Molecular size of the marker was $1000,900,800,700,600,500,400,300,200$ and $100 \mathrm{bp}$. The amplified pattern was visualized on a UV transilluminator and photographed. 


\section{RESULTS}

\section{Antimicrobial Activity}

The antimicrobial activity of Rosmarinus officinalis essential oil on the two examined bacterial strains was shown in Fig. (1). The essential oil had various degrees of inhibition against the two bacterial strains using the drop diffusion method [35].

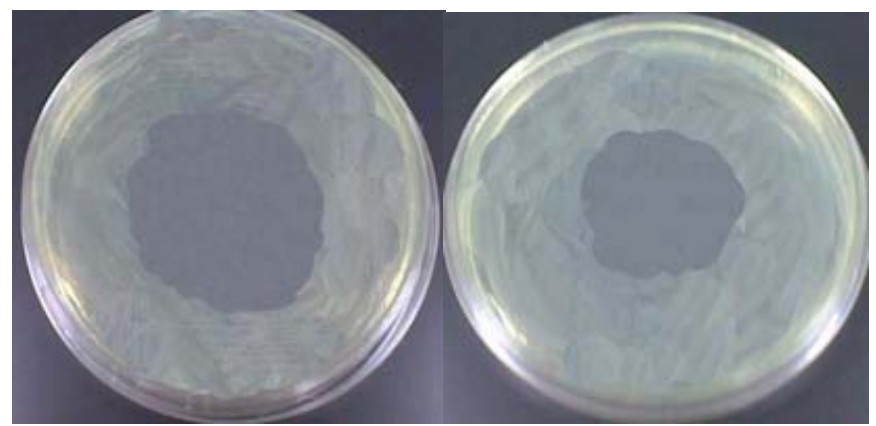

Fig. (1). Inhibition of Staph. aureus (a) and E. coli (b) by rosemary essential oil.

The MIC and MBC values of rosemary EO on the two tested organisms were determined. Rosemary EO exhibited interesting activities against tested bacteria, E. coli and Staph. aureus with MBC values of 2.5 , and $25 \mu \mathrm{ml}^{-1}$, and with MIC values of 1.25 and $5 \mu 1 \mathrm{ml}^{-1}$, respectively.

\section{RAPD Profiling}

The RAPD assay carried out with $50 \mathrm{ng}$ of control genomic DNA and yielded 5-7 bands in case of E. coli and 3-6 bands for Staph. aureus respectively (Fig. 2a, b, c). In total, 5 oligonucleotide primers were used in the analysis and were able to produce reproducible RAPD bands with template DNA from the tested organisms. The presence of changes in the RAPD profiles obtained from the control and exposed bacterial cells to essential oil depended on the primer used. With respect to exposed cells, the number of bands for each primer varied ranging from one band for primer $\mathrm{A} 2$ to ten for primer B3. Polymorphism was evidenced as the presence and / or absence of DNA fragments between the samples (Fig. 2a, b). The DNA profiles generated by the five primers revealed differences between control and exposed bacterial cells, with visible changes in the number and size of amplified DNA fragments, and both increases and decreases of DNA band intensities. Arrows on each gel show some of the obvious modifications (Fig. 2).

Changes in RAPD profiles arose at oil treatment included increase in band intensity, appearance of new bands, and disappearance of some bands (Fig. 2a, $\mathbf{b}, \mathbf{c}$ ). In addition, an appearance of extra bands was the major event arising in the patterns generated by the Staph. aureus cells exposed to rosemary essential oil. In contrast, disappearance of bands was well represented in the patterns produced by $E$. coli exposed to EO (Fig. 2a, b). Band intensity followed two different tendencies, intensity of some bands increased and others decreased respectively, compared to control intensities.

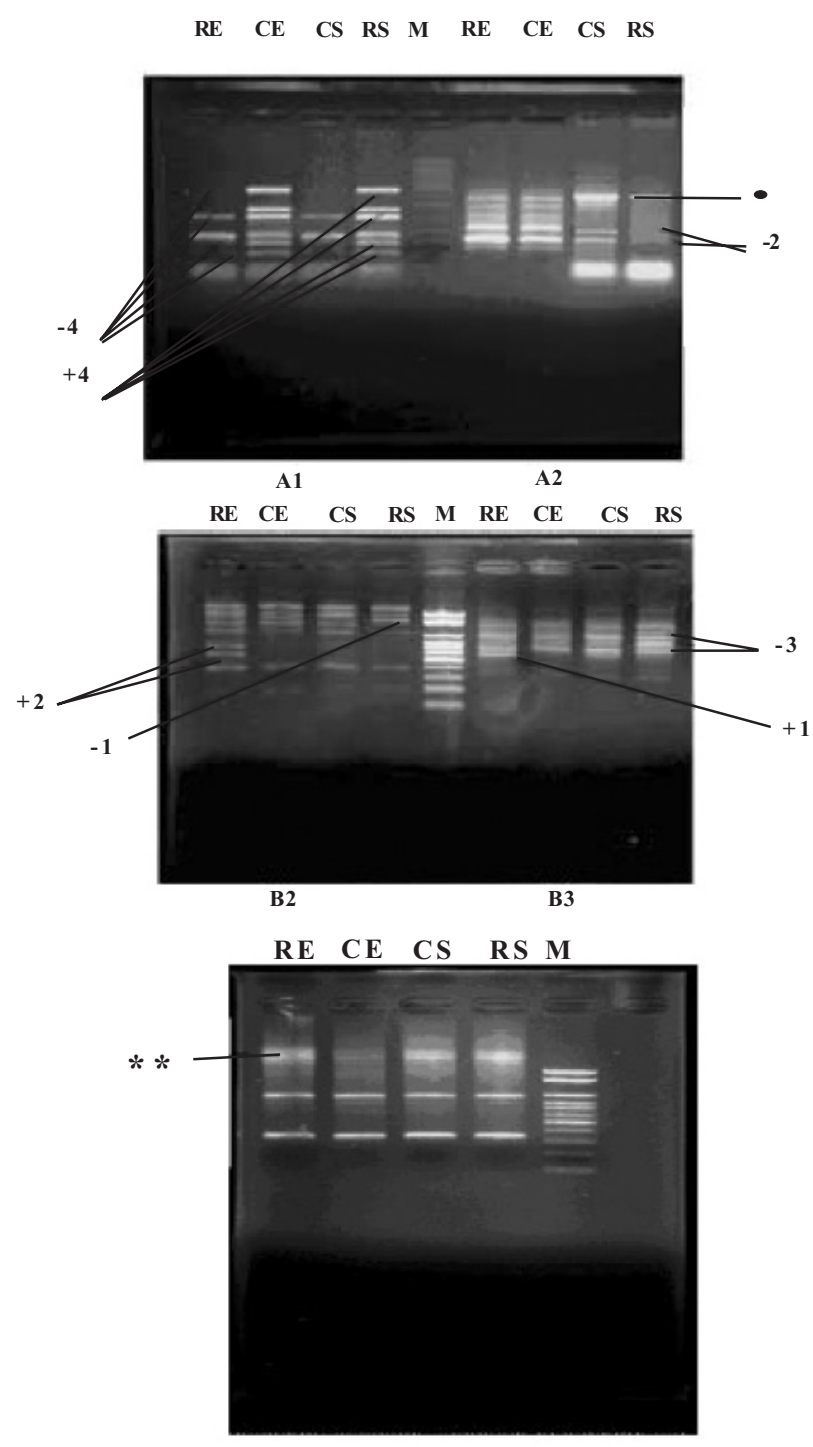

B1

Fig. (2). RAPD profiles of E. coli and $S$. aureus exposed to rosemary essential oil and control. RAPD profiles were generated using 10-mer primers A1, A2, B1, B2 and B3. M, DNA molecular size marker; CE, Control fingerprint of $E$. coli; $\mathrm{CS}$, Control fingerprint of $S$. aureus; RE, The fingerprints of exposed E. coli; RS, The fingerprints of exposed $S$. aureus. Selected changes are indicated by arrows in comparison to control patterns. *decrease in band intensities; ** increase in band intensities + , appearance of a new band; disappearance of a band.

\section{DISCUSSION}

Determination of MIC and MBC of rosemary essential oil against tested bacteria showed that Staph. aureus was more susceptible to the essential oils than E. coli. In accordance with previous findings, it seems that the antibacterial action of the essential oils is more pronounced on Gram- 
positive than on Gram-negative bacteria [36]. Some studies agree that generally rosemary EO are slightly more active against Gram-positive than against Gram-negative bacteria. Gram-negative organisms are less susceptible because they possess another membrane surrounding the cell wall which restricts diffusion of hydrophobic compounds through its lipopolysaccharide covering [6].

In the past decade, the tremendous progress made in molecular biology and genetics resulted in the development of modern diagnostic technologies. These technologies include several extremely sensitive and, most importantly, reliable assays for screening different types of biotic and abiotic environmental agents. RAPD- PCR has proved valuable in many areas of biomedical research [37]. In addition, its use in surveying genomic DNA for evidence of various types of damage and mutation suggest that they may potentially form the basis of novel assays for the detection of DNA damage and mutations [38].

The main changes observed in the RAPD profiles have resulted both in the appearance or disappearance of different bands with variations of their intensity as well. These effects may be correlated with structural rearrangements in bacterial DNA caused by different types of DNA damages. The variation in band intensity and disappearance of some bands may correlate with level of photoproducts in DNA templates after treatment, which can reduce the number of binding sites for Taq polymerase [39].

These new diagnostic assays also permit the detection and characterization of the antimicrobial effects of essential oils commonly used. The RAPD assay is a sensitive, reliable, and rapid method for assessing DNA damage in individual prokaryotic and eukaryotic cells. The results of this work shows that the RAPD technique could be a promising tool in the in vitro detection of alterations in DNA produced by antimicrobial agents, allowing us to see the mechanisms of action of the agent in greater detail. Moreover, the practically unlimited number of informative primers provides a good overall coverage of DNA [40] so that the choice of a set of primers with different sequences will allow increased sensitivity of the assay in the detection of low frequency mutation events.

In conclusion, It has to be emphasized that this diagnosis has been made based on analyses utilizing modern and sensitive assays (RAPD assay) performed on the bacterial cells. The observations indicate that rosemary essential oil can induce wide range of adverse reactions in sensitive individuals.

\section{REFERENCES}

[1] Schilcher H. Sind pflanzliche arzneimittel ttel bzwist die'Naturmedizine' eine gefahr fur den anwender. Arzt Naturheilver Fahren 2002; 43: 253-4.

[2] Longbottom CJ, Carson CF, Hammer CF, Mee BJ, Riley TV. Tolerance of Pseudomonas aeruginosa to Melaleuca alternifolia (tea tree) oil is associated with the outer membrane and energydependent cellular processes. J Antimicrob Chemother 2004; 54: 386-92.

[3] Sonboli A, Eftekhar F, Yousefzadi M, Kanani MR. Antibacterial activity and chemical composition of the essential oil of Grammosciadium platycarpum Boiss. from Iran. Z Naturforsch C 2005; 60: 30-4.

[4] Cowan MM. Plant products as antimicrobial agents. Clin Microbiol Rev 1999; 12: 564-82.
[5] Shanab AB, Ghaleb A, D`ahood AS, Naser J, Kanel A. Antibacterial activity of some plant extract and utilized in popular medicine in Palestine. Turk J Biol 2004, 28: 99-102.

[6] Mounia O, Stéphane C, Linda S, Monique L. Inhibitory effects of selected plant essential oils on the growth of four pathogenic bacteria: E. coli O157:H7, Salmonella Typhimurium, Staphylococcus aureus and Listeria monocytogenes. Food Control 2006; 18 (5): 414-20 .

[7] Conner DE. Naturally occurring compounds. In: Davidson P, Branen AL, Eds. Antimicrobials in Foods. New York: Marcel Dekker, Inc. 1993; pp. 441-68.

[8] Dorman HJD, Deans SG. Antimicrobial agents from plants: antibacterial activity of plant volatile oils. J Appl Microbiol 2000; 88: 308-16.

[9] Deans SG, Ritchie G. Antibacterial properties of plant essential oils. Int J Food Microbiol 1987; 5: 165-80.

[10] Kim J, Marshall MR, Vei C. Antimicrobial activity of some essential oil components against five foodborne pathogens. J Agric Food Chem 1995; 43: 2839-45.

[11] Delaquis PJ, Stanich K, Girard B, Mazza G. Antimicrobial activity of individual and mixed fractions of dill, cilantro, coriander and eucalyptus essential oils. Int J Food Microbiol 2002; 74: 101-9.

[12] Burt SA, Reinders RD. Antimicrobial activity selected plant essential oils against Escherichia coli O157:H7. Lett Appl Microbiol 2003; 36: 162-7.

[13] Iserin P. Encyclopédie des Plantes Médicinales. Larousse/VUEF 2001; p. 128.

[14] Soulier JM. Aromatherapy records 1996; pp. 29-39.

[15] Pintore G, Usai M, Bradesi P, et al. Chemical composition and antimicrobial activity of Rosmarinus officinalis L. oils from Sardinia and Corsica. Flavor Fragrance 2002; 17: 15-19.

[16] Daferera DJ, Ziogas BN, Polissiou MG. The effectiveness of plant essential oils in the growth of Botrytis cinerea, Fusarium sp. and Clavibacter michiganensis subsp. michiganensis. Crop Prot 2003; 22: 39-44.

[17] Burt S. Essential oils: Their antibacterial properties and potential applications in foods - A review. Int J Food Microbiol 2004; 94: 223-53.

[18] Persing DH. Polymerase chain reaction: trenches to benches[Review]. J Clin Microbiol 1991; 29: 1281.

[19] Wagar EA. Direct hybridization and amplification applications for the diagnosis of infectious diseases[Review]. J Clin Lab Anal 1996; 10: 312-25.

[20] Cormican MG, Glennon M, Riain UN, Smith T, Flynn J, Gannon F. Evaluation of a PCR assay for detection of Mycobacterium tuberculosis in clinical specimens. Diag Microbiol Infect Dis 1995; 22: 357-60.

[21] Beavis KJ, Lichty MB, Jungkind DL, Giger O. Evaluation of Amplicor PCR for direct detection of Mycobacterium tuberculosis from sputum specimens. J Clin Microbiol 1995; 33: 2582-6.

[22] Enroth H, Engstrand L. Immunomagnetic separation and PCR for detection of Helicobacter pylori in water and stool specimens. J Clin Microbiol 1995; 33: 2162-5.

[23] Welsh J, Petersen P, McClelland M. Fingerprinting genomes using PCR with arbitrary primers. Nucleic Acids Res 1990; 18: 7213-8.

[24] Hadrys H, Balick M, Schierwater B. Applications of random amplified polymorphic DNA (RAPD) in molecular ecology. Mol Ecol 1992, 1:55-63.

[25] Williams JGK, Hanafey MK, Rafalski JA, Tingey SV. Genetic analysis using random amplified polymorphic DNA markers. Methods Enzymol 1993; 218: 704-40.

[26] Kim J, Kim S, Kwon N, et al. Isolation and identification of Escherichia coli $\mathrm{O} 157: \mathrm{H} 7$ using different detection methods and molecular determination by multiplex PCR and RAPD. J Vet Sci 2005; 6(1): 7-19.

[27] Goswitz JJ, Willard KE, Fasching CE, Peterson LR. Detection of gyrA gene mutations associated with ciprofloxacin resistance in methicillin-resistant Staphylococcus aureus: analysis by polymerase chain reaction and automated direct DNA sequencing. Antimicrobiol Agents Chemother 1992; 36: 1166-9.

[28] Atienzar FA, Cordi B, Donkin M, Evenden A, Jha A, Depledge AM. Comparison of ultraviolet-induced genotoxicity detected by random amplified polymorphic DNA with chlorophyll fluorescence and growth in a marine macroalgae. Palmaria palmata. Aquat Toxicol 2000; 50: 1-12. 
[29] Baratta MT, Dorman HJ, Deans SG, Figueiredo AC, Barroso JG, Ruberto G. Antimicrobial and Antioxidant properties of some commercial essential oils. Flavor Fragrance 1998; 13: 235-44.

[30] May J, Chan CH, King A, Williams L, French GL. Time-kill studies of tea tree oils on clinical isolates. J Antimicrob Chemother 2000; 45: 639-43.

[31] Canillac N, Mourey A. Antibacterial activity of essential oil of Picea exelsa on Listeria, Staphylococcus aureus and coliform bacteria. Food Microbiol 2001; 18: 261.

[32] Ronda L, Akins M, Rybak J. Bactericidal activities of two daptomycin regimens against clinical strains of glycopeptide intermediate-resistant Staphylococcus aureus, vancomycin-resistant Enterococcus faecium, and methicillin-resistant Staphylococcus aureus isolates in an in vitro pharmacodynamic model with simulated endocardial vegetations. Antimicrob Agents Chemother 2001; 45: 454-9.

[33] Doyle JJ, Doyle JL. Isolation of plant DNA from fresh tissue. Focus 1990; 12: 13-15.

[34] Sambrook J, Fritsch EJ, Maniatis T. Molecular cloning: a laboratory manual. New York: Cold Spring Harbor 1989.
[35] Hili P, Evans CS, Veness RG. Antimicrobial action of essential oils: the effect of dimethylsulphoxide on the activity of cinnamon oil. Lett Appl Microbiol 1997; 24(4): 269-75.

[36] Ali NAA, Julich W, Kusnick C, Lindequist U. Screening of Yemeni medicinal plants for antimicrobial and cytotoxic activities. J Ethnopharmacol 2001; 74: 173-9.

[37] Williams JAR, Kubelik JK, Livak JA, Rafalski JA, Tingey SV. DNA polymorphism amplified by arbitrary primers are useful as genetic markers. Nucleic Acids Res 1990; 18: 6535.

[38] Atienzar FA. Development of the random amplified polymorphic DNA (RAPD) technique to measure the effects of genotoxins in aquatic organisms. Ph.D. Thesis (DXN034438). UK: University of Plymouth 2000.

[39] Petti CA, Polage CR, Schreckenberger P. The role of 16S rRNA gene sequencing in identification of microorganisms misidentified by conventional methods. J Clin Microbiol 2005; 43: 6123-5.

[40] Ramser, Lopez-Peralta C, Wetzel R, Weising K, Kahl G. Genomic variation and relationships in aerial yam (Dioscores bulbifera L.) detected by ramdon amplified polymorphic DNA. Genome 1996; 39: 1725 .

\section{(C) Hend A. Hamedo; Licensee Bentham Open.}

This is an open access article licensed under the terms of the Creative Commons Attribution Non-Commercial License (http://creativecommons.org/licenses/by-nc/3.0/) which permits unrestricted, non-commercial use, distribution and reproduction in any medium, provided the work is properly cited. 